\title{
IMMUNOGENICITY AND CHARACTERISTICS OF M PRO- TEIN RELEASED BY PHAGE-ASSOCIATED LYSIN FROM GROUP-A STREPTOCOCCI TYPES 1 AND 23
}

\author{
J. O. Cohen, H. Gross and W. K. Harrell \\ Biological Products Division, Center for Disease Control, Public Health Service, U.S. \\ Department of Health, Education and Welfare, Atlanta, Georgia 30333, USA
}

\section{Plates XI AND XII}

THE M protein of group-A streptococci is an important type-specific antigen related to virulence. The antigen is usually extracted from cells or cell walls into dilute hydrochloric acid and saline at $p \mathrm{H} 2$ by heating at $100^{\circ} \mathrm{C}$ for $10 \mathrm{~min}$. (Lancefield, 1940; Lancefield and Perlmann, 1952). The M protein obtained in this way reacts with specific antisera in the precipitin test and will elicit bactericidal and haemagglutinating antibodies when injected into rabbits (Fox and Wittner, 1966). However, rabbits exhibit a poor precipitin response to acid-extracted M protein (ACID-M) (Fox, 1964; Fox and Wittner, 1965, 1966). Therefore, specific typing antisera for group-A streptococci are routinely prepared by the Lancefield (1940) method of immunising rabbits with heatkilled streptococci and removing cross-reactions for the precipitin test by absorbing with heterologous strains.

A phage-associated lysin (PAL) from group-C streptococci lyses group-A cells or cell walls with release of some of the $\mathbf{M}$ protein (lysin-released $\mathbf{M}$ protein; LYSIN-M). In two reports, LYSIN-M was shown to be of higher molecular weight than ACID-M (Krause, 1958; Kantor and Cole, 1960). Antisera from rabbits immunised with LYSIN-M contained both precipitating and bactericidal antibodies (Kantor and Cole, 1960). The current work was initiated to find out if standard streptococcal M-typing antisera could be prepared in rabbits by immunisation with soluble LYSIN-M and, furthermore, if the procedures developed would be useful for producing antisera difficult to prepare by whole-cell vaccine procedures.

This paper reports the successful production of LYSIN-M from types 1 and 23. It also describes the partial purification and some properties of LYSIN-M preparations and the successful production in rabbits of potent specific precipitin typing antisera with bactericidal activity. Attempts to produce antiserum for type-13 M protein, a difficult type, by the same procedures failed.

\section{MATERIALS AND METHODS}

Strains. Strains of group-A streptococci used in this study were from the culture collection of the Bacterial and Fungal Products Branch of the Center for Disease Control (CDC),

Received 5 Mar. 1976; revised version accepted 17 Sept. 1976.

J. MED. MICROBIOL.--voL. 10 (1977)

179 
Atlanta, Ga, except for strain DS-1134-66 (type T1, M negative) obtained from J. Padula, Clinical Bacteriology Branch, CDC. Strains were received as cultures stored at $-60^{\circ} \mathrm{C}$ in defibrinated rabbit blood. In the present study strains 0001/B1 type 1, 0223/B1 type 23, 0098/B1 type 13, and DS-1134-66 were stored at $-60^{\circ} \mathrm{C}$ in $0.05 \%(\mathrm{w} / \mathrm{v})$ aqueous neutralised cysteine hydrochloride (Pine and Watson, 1959).

Antisera. Specific antisera for the various types of $\mathbf{M}$ protein studied and for streptococcal groups A and D were from the Biological Products Division of CDC. Antisera and antigen preparations for serum-gel double-diffusion indentification of type-1 $\mathbf{M}$ protein, type-1 T protein, and polyalanine-glycerophosphate (anitgen E-4) (Wilson and Wiley, 1963) were provided by J. H. Green of CDC.

Precipitin tests. Qualitative M-protein determinations were performed by the capillary precipitin method of Swift, Wilson and Lancefield (1943). Quantitative M-protein capillaryprecipitin tests were performed by the method of Cohen and Pine (1968). For type 1, a frozen lot of ACID-M was used as standard. Type-23 M protein units were determined on a dilution curve of a type-23 LYSIN-M preparation. The units for types 1 and types 23 were arbitrary.

Streptococcal group-A carbohydrate was identified by a ring precipitin test between serum and antigen in capillary tubes (Swift et al., 1943).

Bactericidal test. The indirect bactericidal test of Lancefield (1957) was performed to determine the presence of antibodies to $\mathbf{M}$ protein capable of opsonising homologous living streptococci for phagocytosis by human leucocytes.

Double-diffusion tests. These were done with slides $(7.5 \mathrm{~mm} \times 2.5 \mathrm{~mm})$. The medium, suggested by Dr Shirley Maddison of CDC, contained (w/v) Noble Agar (Difco) $1 \%$, sodium chloride $0.85 \%$, glycine $0.75 \%$ and sodium azide $0.05 \%$. The $p \mathrm{H}$ was adjusted to 7.4 with small amounts of $0 \cdot 1 \mathrm{~N}$ sodium hydroxide. The medium was autoclaved at $121^{\circ} \mathrm{C}$ for $10 \mathrm{~min}$.

Protein estimations. Protein usually was determined by the method of Lowry et al. (1951), with a serum solution of known protein content used for reference (normal rabbit serum diluted 1 in 200 and standardised against a certified bovine serum albumin). Protein in type23 LYSIN-M was estimated by comparing the ultraviolet absorption at $280 \mathrm{~nm}$ with that at $260 \mathrm{~nm}$ according to the formula of Layne (1957): protein $(\mathrm{mg}$ per $\mathrm{ml})=1.55 \times \mathrm{D} 280-0.76$ $\times$ D260. ( $D=$ absorbence at the respective wavelength.)

Growth of streptococci for LYSIN-M production. A 200-ml centrifuge bottle of ToddHewitt Broth (Difco) was inoculated with several drops of the appropriate thawed streptococcal suspension. The bottle was incubated at $37^{\circ} \mathrm{C}$ for $10-12 \mathrm{~h}$. Six to 12 flasks of ToddHewitt Broth ( $500 \mathrm{ml}$ in a 1-litre flask) were each inoculated with $15 \mathrm{ml}$ of the starter culture and were incubated for $10-12 \mathrm{~h}$ at $37^{\circ} \mathrm{C}$. Young cultures were used because earlier studies (Cohen, 1969) showed that, during the logarithmic phase of growth in Todd-Hewitt Broth, M-protein production parallels cell growth, and proteinase activity in proteinase-producing strains, such as $0001 / \mathrm{B} 1$, is minimal or absent. The cells were harvested by centrifugation at $600 \mathrm{~g}$, washed once with $0.02 \mathrm{M}$ phosphate buffer, $p \mathrm{H} 6.1$ (PB) and were then suspended in a few $\mathrm{ml}$ of the same buffer containing $0.1 \%$ of neutralised thioglycollic acid $(p \mathrm{H} \mathrm{6.0)}$ or, in the case of type 23, $0.5 \mathrm{~nm}$ dithiothreitol (DTT) and neutralised $5 \mathrm{~mm}$ ethylenediaminotetraacetic acid (EDTA). The suspensions contained about $10^{11}$ or $10^{12}$ colony-forming units of streptococci per ml.

Phage-associated lysin. Lysin was produced by infecting a group-C streptococcal strain 26RP66 with the virulent phage $C^{\prime}$. The method of preparation, stabilisation, partial purification, storage, and assay of PAL was recently reported (Cohen, Gross and Harrell, 1975).

Release of LYSIN-M. Viable cells were lysed in a solution that contained $0.04 \mathrm{ml}$ of PAL, $0.1 \mathrm{ml}(20 \mu \mathrm{g})$ of RNAase (Worthington Biochemical Corporation, Freehold, NJ, crystalline), $0.2 \mathrm{ml}$ of $0.05 \mathrm{M}$ DTT, $0.1 \mathrm{ml}$ of $0.5 \mathrm{M}$ EDTA and $9.1 \mathrm{ml}$ of $0.02 \mathrm{M} \mathrm{PB}, p \mathrm{H} 6.1$. In the case of type 1 strains, $0.4 \mathrm{ml}$ of $2 \%$ neutralised thioglycollic acid was used instead of DTT. This reaction mixture was dispensed in each of 10-20 tubes. To each tube was added $0.1 \mathrm{ml}$ of the streptococcal suspension, and the tubes were incubated for $5-15 \mathrm{~min}$. at $37^{\circ} \mathrm{C}$, during which time complete lysis appeared to take place. The tubes were removed from the 
waterbath. A further $0.1 \mathrm{ml}$ of cell suspension was added to each tube and the tubes were then re-incubated for $10 \mathrm{~min}$. at $37^{\circ} \mathrm{C}$. This process was repeated seven to ten times. To ensure the reducing conditions necessary to maintain the PAL in active form, $0 \cdot 1 \mathrm{ml}$ of DTT (or neutralised thioglycollic acid) was added twice during the repeated lytic cycles. After the third lytic period, a flocculent sediment appeared in the lysate, and this material continued to increase during subsequent lytic periods. After the last lytic period, the material in the tubes was transferred to $40-\mathrm{ml}$ glass conical centrifuge tubes and centrifuged at $600 \mathrm{~g}$ for 40 min. The supernatant fluid in each centrifuge tube was tested for viable streptococci by streaking a loopful on blood agar. Usually after successful lysis, few if any colonies of streptococci appeared on the plates after overnight incubation at $37^{\circ} \mathrm{C}$. Microscopic examination showed gram-negative debris, with few intact gram-negative cocci and no chains.

The supernatant fluid was kept at $4^{\circ} \mathrm{C}$ overnight and then centrifuged at $12000 \mathrm{~g}$ at $4^{\circ} \mathrm{C}$ for $45 \mathrm{~min}$. This second centrifugation sedimented debris that had remained in suspension after the initial slow-speed centrifugation. In the case of type-1 strain 0001/B1, the opalescent supernatant fluid after this centrifugation contained LYSIN-M. Recovery of LYSIN-

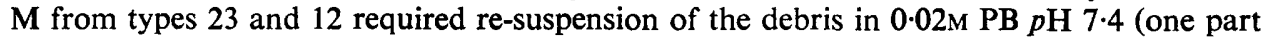
sediment to six parts buffer, $v / v$ ), mechanical agitation on a Vortex-Genie (Scientific Industries Springfield, Mass.) mixer at setting no. 4 for $5 \mathrm{~min}$. and then centrifugation at $12000 \mathrm{~g}$ at $4^{\circ} \mathrm{C}$ for $1 \mathrm{~h}$. This treatment dissolved some of the LYSIN-M.

Ammonium-sulphate precipitation of type-1 LYSIN-M. Crystalline ammonium sulphate was added with constant stirring at $4^{\circ} \mathrm{C}$ to the clarified supernatant fluid to a final concentration of $30 \%$ saturation as suggested by Lancefield and Perlmann (1952). The suspension was allowed to stand in the refrigerator for $2 \mathrm{~h}$ then centrifuged at $12000 \mathrm{~g}$ at $4^{\circ} \mathrm{C}$ for $1 \mathrm{~h}$. The precipitate contained little if any LYSIN-M and was discarded. Crystalline ammonium sulphate was added to the supernatant fluid with constant stirring at $4^{\circ} \mathrm{C}$ to bring the solution to $60 \%$ saturation (Lancefield and Perlmann, 1952), and a fine cloudy precipitate formed after overnight incubation at $4^{\circ} \mathrm{C}$. The precipitate, containing LYSIN-M, was harvested by centrifugation at $20000 \mathrm{~g}$ and $4^{\circ} \mathrm{C}$ for $1 \mathrm{~h}$. The supernatant fluid, containing some of the group carbohydrate and antigens other than $\mathbf{M}$ protein, was discarded. The precipitate was dis-

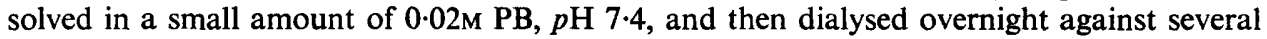
changes of the same buffer at $4^{\circ} \mathrm{C}$ to remove the residual ammonium sulphate from the LYSIN-M solution.

Immunisation of rabbits. Adult New Zealand white rabbits from the specific-pathogenfree colony of CDC were used. In early experiments, rabbits were given dialysed ammoniumsulphate-precipitated type-1 LYSIN-M into the footpads in a series of nine weekly injections of $1 \mathrm{mg}$ of protein without adjuvant. In a later experiment, type-1 purified LYSIN-M was

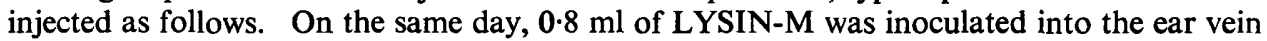
and $1.6 \mathrm{ml}$ of a mixture of half LYSIN-M and half Freund's complete adjuvant was injected into the front footpads. (The M-protein units and specific activities of these preparations (the fractions from stages 3 and 4) are listed in table IV.) Rabbits were immunised with type23 purified LYSIN-M by the footpad route on one day with a total of $1.8 \mathrm{ml}$ of a vaccine in Freund's complete adjuvant. The vaccine for rabbits nos. 34, 36 and 37 contained 1150 units of type-23 LYSIN-M in about $1.4 \mathrm{mg}$ of protein. Rabbit no. 35 received only 500 units of type-23 LYSIN-M in about $600 \mu \mathrm{g}$ of protein.

Sephadex G-200 gel-filtration of type-1 LYSIN-M. A sample of $14 \mathrm{mg}$ (in $6.4 \mathrm{ml}$ ) of type-1 LYSIN-M partially purified by ammonium-sulphate precipitation and RNAase treatment was applied to a Sephadex G-200 column $(50 \mathrm{~cm} \times 2.5 \mathrm{~cm})$ and was eluted with $0.02 \mathrm{M} \mathrm{PB}$, $p \mathrm{H} \mathrm{7.4,} \mathrm{at} \mathrm{a} \mathrm{rate} \mathrm{of} 10 \mathrm{ml}$ per hour; $5.0 \mathrm{ml}$ fractions were collected on a fraction collector. The void volume was $120 \mathrm{ml}$. Fractions 25 to 52 were assayed for total protein, M protein (quantitative tests), and group carbohydrate (qualitative tests).

Ultraviolet absorption by LYSIN-M. Ultraviolet absorption at $280 \mathrm{~nm}$ and $260 \mathrm{~nm}$ was determined for various preparations of LYSIN-M types with a Beckman D.U. Model 24 spectrophotometer.

Immunoabsorbent column. The $\gamma$-globulin fraction from an antiserum with high activity against group-A group polysaccharide, prepared by immunisation of rabbits with heat-killed 


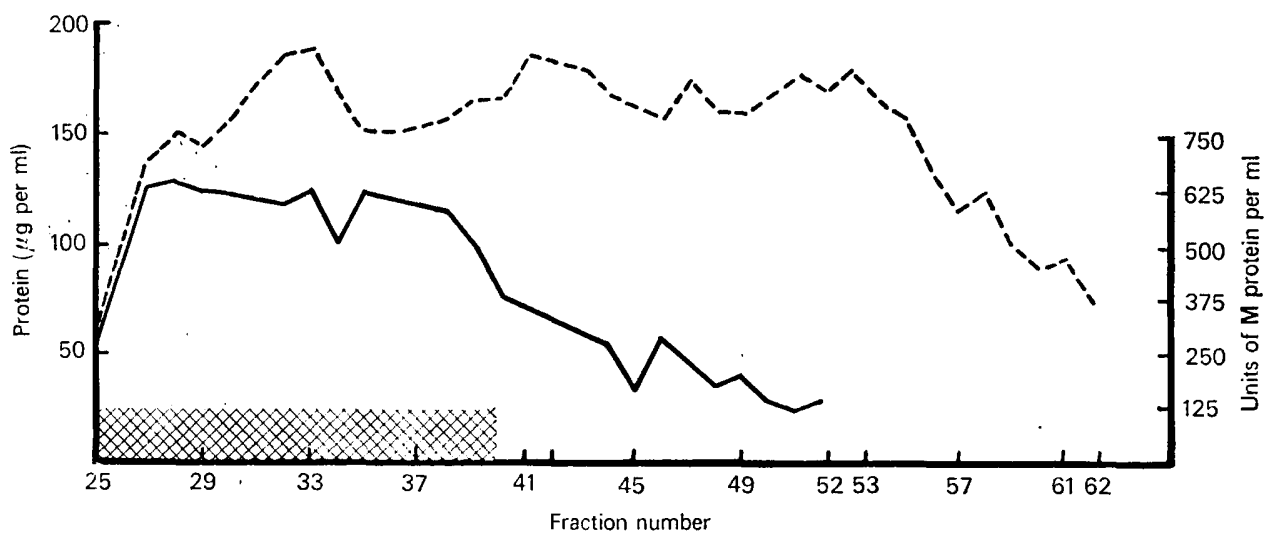

FIG. 1.-Sephadex G-200 gel-filtration of ammonium-sulphate precipitated type-1 LYSIN-M: $--=$ total protein; $-=\mathbf{M}$ protein; cross hatching = qualitative assay for group $\mathbf{A}$ carbohydrate. The first 24 fractions contained the void volume of the column.

cells of an M-protein-negative group-A streptococcal strain, was conjugated to Sepharose 6B by means of the cyanogen-bromide method of Axen, Porath and Ernback (1967).

Partial purification of type-23 LYSIN-M. This was purified by precipitation at its isoelectric point by dialysing $45 \mathrm{ml}$ of the LYSIN-M solution against 2.25 litres of $6.25 \mathrm{~mm}$ sodium acetate buffer, $p \mathrm{H} 4.9$, at $4^{\circ} \mathrm{C}$ for $17 \mathrm{~h}$. The precipitate was collected by centrifugation (19 000 g at $4^{\circ} \mathrm{C}$ for $1 \mathrm{~h}$ ), redissolved in $20 \mathrm{ml}$ of $0.02 \mathrm{M}$ phosphate-buffered saline, $p \mathrm{H} \mathrm{7.5}$ (PBS), and re-precipitated by dialysis for $22 \mathrm{~h}$ against the $p \mathrm{H} 4.9$ acetate buffer. After centrifugation as before, the second precipitate was dissolved in $10 \mathrm{ml}$ of $0.02 \mathrm{M}$ PBS, $p \mathrm{H} \mathrm{7.5}$.

Deoxyribonuclease (DNAase) treatment. To $8 \mathrm{ml}$ of partially purified type-23 LYSIN-M was added $0.1 \mathrm{ml}(85 \mu \mathrm{g})$ of DNAase (Worthington, once crystallised, containing 2620 units per $\mathrm{mg}$ and free of proteinase activity). The mixture was incubated at $23^{\circ} \mathrm{C}$ for $2.5 \mathrm{~h}$ and then dialysed against $0.02 \mathrm{M}$ PBS, $p \mathrm{H} \mathrm{7.5}$, at $4^{\circ} \mathrm{C}$ for $24 \mathrm{~h}$, with three changes of buffer. DNAasetreated type-23 LYSIN-M was used to immunise rabbits.

Electron micrograph. After a sequence of 11 lytic periods, the sediment from treatment of strain 0098/B1, type 13, with PAL was examined under the electron microscope. A drop of suspension was placed on formvar-coated grids. The grids were stained with $2 \%$ aqueous uranyl acetate and examined in a Phillips 200 Electron Microscope.

\section{RESULTS}

\section{Type-1 LYSIN-M}

Soluble type-1 LYSIN-M was found in the supernatant fluid of the lysate after sequential lysis of strain 0001/B1. The LYSIN-M was concentrated by precipitation with ammonium sulphate at $60 \%$ saturation. Material from several runs was pooled. A portion of this material was passed through a Sephadex G-200 column and another portion was used to immunise three rabbits.

Sephadex G-200 gel-filtration. The results obtained by passing ammoniumsulphate-precipitated LYSIN-M (14 mg total protein) through a Sephadex G-200 column are shown in fig. 1. M protein appeared in the eluate just beyond the void volume and was found in fractions 25 to 52 . This indicated that much of the $\mathbf{M}$ protein was of relatively high molecular weight, perhaps as great as 
200000 . Lower molecular weight material with $\mathbf{M}$ protein activity was also present, as indicated by the broad spread of $M$ activity. Group A carbohydrate was present in fractions 25 to 42 . Concentration of later fractions that were weak in $M$ protein indicated that these also reacted with group A antiserum. Although the protein elution profile showed little resolution, a substantial amount of protein eluted after the $M$ protein, indicating that partial purification could be obtained by gel filtration. However, the failure to obtain a more narrow band of M-protein activity discouraged us from using gelfiltration as a primary method for purifying LYSIN-M.

Immunogenicity of type-1 LYSIN-M. Each of three rabbits immunised with type-1 LYSIN-M, concentrated by ammonium-sulphate precipitation, responded with the production of precipitins for both LYSIN-M and ACID-M, but only two antisera (from rabbits 10 and 11) exhibited strong reactions for both antigens. The bactericidal activities, determined by the indirect bactericidal test, are shown in table I.

The antisera from these two rabbits did not react with group-A extracts. In the capillary precipitin test, the antisera exhibited numerous cross-reactions with acid extracts or lysin-prepared extracts of heterologous types.

Serum-gel diffusion slides were set up with known antisera and antigens in wells adjacent to antisera prepared in rabbit 10 or 11 , so that reactions of identity could be observed. An example of serum-gel analysis of type-1 LYSIN-M rabbit-11 antiserum, and comparison with reference antisera and antigens is shown in fig. $2 b$. By this method, precipitin lines were observed with type-1 $M$ protein and type-1 T protein against LYSIN-M antisera. The antisera also exhibited lines with heat-labile antigen(s) (missing from acid-heat extracts) that cross-reacted with antigens from heterologous crude LYSIN-M preparations (see fig. $2 a$ ).

TABLE I

Indirect bactericidal activity for strain 0001/B1 of antisera from rabbits immunised with ammonium sulphate-precipitated type-1 LYSIN-M

\begin{tabular}{|c|c|c|c|c|c|}
\hline \multirow[t]{2}{*}{ Serum sample } & \multicolumn{5}{|c|}{$\begin{array}{l}\text { Viable counts (c.f.u. per } 0 \cdot 1 \mathrm{ml} \text { ) after } 3 \text { hours' } \\
\text { incubation of mixtures of serum and heparinised } \\
\text { human blood that initially contained the } \\
\text { following number of c.f.u. per tube. }\end{array}$} \\
\hline & 143 & 35 & 22 & 8 & 1 \\
\hline $\begin{array}{l}\text { Normal rabbit serum } \\
\text { Rabbit } 10,3 \text { rd bleeding } \dagger \\
\text { Rabbit } 10,4 \text { th bleeding } \ddagger \\
\text { Rabbit } 11,3 \text { rd bleeding } \dagger \\
\text { Rabbit } 11,4 \text { th bleeding } \ddagger\end{array}$ & $\begin{array}{r}U^{*} \\
500 \\
312 \\
600 \\
91\end{array}$ & $\begin{array}{r}316 \\
0 \\
0 \\
0 \\
0\end{array}$ & $\begin{array}{r}40 \\
0 \\
0 \\
0 \\
0\end{array}$ & $\begin{array}{r}73 \\
0 \\
0 \\
0 \\
0\end{array}$ & $\begin{array}{l}0 \\
0 \\
0 \\
0 \\
0\end{array}$ \\
\hline
\end{tabular}

c.f.u. = colony-forming units.

* Uncountable.

$\dagger$ One week after the 5th weekly injection.

$\$$ One week after the 6th weekly injection. 
TABLE II

Specific activities of type-1 LYSIN-M preparations

\begin{tabular}{c|cccc}
\hline $\begin{array}{c}\text { Preparation } \\
\text { no. }\end{array}$ & $\begin{array}{c}\text { Volume } \\
\text { (ml) }\end{array}$ & $\begin{array}{c}\text { M protein } \\
\text { (units per } \mathrm{ml}^{*} \text { ) }\end{array}$ & $\begin{array}{c}\text { Total protein } \\
\text { (mg per ml } \dagger \text { ) }\end{array}$ & $\begin{array}{c}\text { Specific activity } \\
\text { (units per mg } \\
\text { of protein) }\end{array}$ \\
\hline & & & & \\
1 & $10 \cdot 1$ & 8400 & $3 \cdot 7$ & 2260 \\
2 & $9 \cdot 7$ & 7000 & $3 \cdot 3$ & 2120 \\
3 & $10 \cdot 0$ & 9000 & $3 \cdot 6$ & 2500 \\
4 & $10 \cdot 5$ & 5300 & $3 \cdot 5$ & 1520 \\
5 & $11 \cdot 0$ & 6100 & $3 \cdot 9$ & 1560 \\
\hline
\end{tabular}

* Determined by the method of Cohen and Pine (1968).

$\dagger$ Determined by the method of Lowry et al. (1951).

Antiserum from rabbit 11, taken 1 week after the last injection, was absorbed twice with heat-killed $\left(56^{\circ} \mathrm{C}\right.$ for $\left.1 \mathrm{~h}\right)$ cells of streptococci of types 9 and 55 . The resulting antiserum reacted moderately strongly with acid-heat extracts of strain 0001/B1 (type 1), but did not react with extracts of types 2 to 60 inclusive in the capillary precipitin test.

Cross-reactions of specific typing antisera. Specific typing antisera prepared by whole-cell immunisation and absorbed with heterologous strains were tested against ammonium sulphate-precipitated LYSIN-M preparations of types 1, 5, 6,12 and 24 in the capillary precipitin test. All of the antisera tested reacted with heterologous LYSIN-M preparations. These reactions could be eliminated by heating the LYSIN-M preparations at $100^{\circ} \mathrm{C}$ and $p \mathrm{H}$ for $10 \mathrm{~min}$. These results indicate that the specificity of the Lancefield typing antisera depends on the inactivation of heat-labile antigens in the preparation of acid extracts of diagnostic strains and that the typing antisera are not monovalent, except in the context of the test conditions recommended. Activity for type-1 T protein was also present in our type-1 antiserum, as demonstrated by serum-gel diffusion experiments.

Further study of type-1 $L Y S I N-M$. The specific activities of five preparations of ammonium-sulphate-precipitated type-1 LYSIN-M are shown in table II. All five preparations showed greater ultraviolet absorbence at $280 \mathrm{~nm}$ than at $260 \mathrm{~nm}$ and were similar in serum-gel diffusion experiments.

Serum-gel experiments were performed to identify antigens in these LYSIN$M$ preparations and to determine the nature of any contaminating antigens. The type-1 LYSIN-M preparations exhibited a reaction of identity with a known type-1 ACID-M, when tested against both unabsorbed and specific type-1 antisera. In addition to this M-protein line, lines representing heat labile antigen(s), type-1 T protein (Lancefield, 1940), poly-alanine glycerophosphoric acid (E-4) and group-A carbohydrate were observed. However, when LYSIN-M preparations were injected into rabbits, E-4 and Group A carbohydrate did not appear to be immunogenic. Apparently these antigens behave as haptens and are immunogenic only when whole-cell vaccines are used. 
Precipitation of type-1 LYSIN-M by group- $A$ antiserum. Previously we observed that significant amounts of group-A carbohydrate coprecipitated with type-1 $\mathrm{M}$ protein when ammonium sulphate to $60 \%$ saturation was added to LYSIN-M. Furthermore, $M$ protein and group-A carbohydrate appeared in the same fractions after Sephadex G-200 gel-filtration of type-1 LYSIN-M. The results suggested that at least some group-A carbohydrate is bound to $\mathbf{M}$ protein as previously reported by Kantor and Cole (1960) and Barkulis (1968). To test this possibility, an experiment was designed to determine whether significant amounts of $\mathrm{M}$ protein could be precipitated from type-1 LYSIN-M by group-A antiserum.

Two sets of dilutions of type-1 LYSIN-M were made so that after addition of equal volumes of antiserum $(0.2 \mathrm{ml})$ to the tubes, the dilutions of LYSIN-M were 1 in 4, 1 in 8 and 1 in 16 respectively. Group-A antiserum was added to one set of the LYSIN-M dilutions and group-D antiserum to the other. The contents were mixed gently and the tubes allowed to stand at $26^{\circ} \mathrm{C}$ for $20 \mathrm{~min}$. Then both sets of tubes were centrifuged at $600 \mathrm{~g}$ for $20 \mathrm{~min}$. The supernatant fluids were tested for residual type- $1 \mathrm{M}$ protein by reaction with specific type-1 antiserum in the quantitative capillary-precipitin test (Cohen and Pine, 1968). The results are shown in table III. The dilutions of type-1 LYSIN-M, treated with group-D antiserum, represent the initial concentrations of reactive type-1 protein. When type-1 LYSIN-M had been pretreated with group-A antiserum, smaller amounts of $M$ precipitate formed at all three dilutions than those found after pretreatment with group-D antiserum. The effect was most striking at the 1 in 4 dilution. This indicates that at least some of the type- $1 \mathrm{M}$ protein is bound to group-A carbohydrate.

Immunoabsorbent-column purification of type-1 LYSIN-M. The immunoglobulin fraction of an antiserum for an M-negative group-A strain, high in group-carbohydrate activity, was conjugated to Sepharose $6 \mathrm{~B}$ by means of cyanogen bromide (Axen et al., 1967). Two ml (6.6 mg) of type-1 LYSIN-M

TABLE III

Evidence for precipitation of type-1 LYSIN-M by group- $A$ antiserum

\begin{tabular}{c|cc}
\hline $\begin{array}{c}\text { Dilution of } \\
\text { type-1 } \\
\text { LYSIN-M* }\end{array}$ & $\begin{array}{c}\text { Result of quantitative capillary-precipitin test for M protein } \dagger \\
\text { in supernatant fluid after treatment with }\end{array}$ \\
\hline & group-A antiserum & group-D antiserum \\
1 in 4 & 184 & 300 \\
1 in 8 & $93 \ddagger$ & 118 \\
1 in 16 & 72 & 107 \\
\hline
\end{tabular}

* Dilution of type-1 LYSIN-M after addition of an equal volume $(0.2 \mathrm{ml})$ of group-A or group$\mathrm{D}$ antiserum. Reaction mixtures were incubated at $26^{\circ} \mathrm{C}$ for $20 \mathrm{~min}$. and then centrifuged to remove precipitate. Supernatant fluids were tested for residual reactivity with type-1 $\mathbf{M}$ antiserum.

$\dagger$ Quantitative precipitin test by the method of Cohen and Pine (1968). Results, given as weight $(\mathrm{mg})$ of paper images, reflect the amount of precipitate in the capillaries. Each value is an average of three of four capillaries (except the value marked $\ddagger$ ).

+ Average of two capillaries. 
TABLE IV

Purification of type-1 LYSIN-M on an immunoabsorbent column containing antibody for group-A carbohydrate*

\begin{tabular}{|c|c|c|c|c|c|}
\hline Stage & $\begin{array}{l}\text { Column } \\
\text { treatment }\end{array}$ & $\begin{array}{l}\text { Volume }(\mathrm{ml}) \text { after } \\
\text { concentration }\end{array}$ & $\begin{array}{c}\text { M protein } \\
\text { (units per ml) }\end{array}$ & $\begin{array}{l}\text { Specific activity } \\
\text { (M-protein units } \\
\text { per mg of protein) }\end{array}$ & $\begin{array}{l}\text { Total units } \\
\text { of } M \text { protein }\end{array}$ \\
\hline 1 & Initial eluate & 5 & 910 & & 4550 \\
\hline 2 & $\begin{array}{c}\text { Borate buffer, } \\
p \mathrm{H} 8.0\end{array}$ & 8 & 0 & 0 & 0 \\
\hline 3 & Glycine- $\mathrm{HCl}$ & 8 & 1120 & 3700 & 8960 \\
\hline 4 & $\begin{array}{l}0.1 \mathrm{~N} \mathrm{NaOH} \\
\text { eluate }\end{array}$ & 6.5 & 630 & $133 t$ & 4095 \\
\hline
\end{tabular}

* Details of procedures are given in Materials and methods.

$\dagger$ Sum of $M$ protein recoveries at different stages, taking account of experimental error, was $100 \%$. $\ddagger$ Low specific activity of stage-4 material appeared to be due to removal of $\gamma$ globulin as well as $\mathrm{M}$ protein by $0 \cdot 1 \mathrm{~N} \mathrm{NaOH}$.

was passed through the column $(20 \mathrm{~cm} \times 1 \cdot 25 \mathrm{~cm})$ (stage 1). This was followed

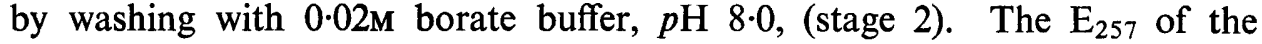
eluate was monitored and buffers were changed after return of absorbence to base-line values. The column was eluted with $0.066 \mathrm{M}$ glycine- $\mathrm{HCl}$ buffer, $p \mathrm{H} 2.65$ (stage 3) and then with $0 \cdot 1 \mathrm{M} \mathrm{NaOH}$ (stage 4). The fractions were

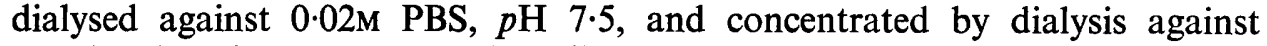
powdered sodium carboxymethylcellulose.

The four fractions were assayed for $\mathrm{M}$ protein quantitatively (Cohen and Pine, 1968) and for total protein (Lowry et al., 1951), and the specific activities of $\mathbf{M}$ protein in the eluted fractions were determined (table IV). The M-protein positive fractions were also tested by serum-gel-diffusion against reference antisera and antigens for $M$ protein, $T$ protein, E-4 and heat-labile antigens. At stage 1 , the material that did not adhere contained some $M$ protein, $T$ protein, E-4 and heat-labile antigens. Stage 2 material contained no $M$ protein and was not analysed further. Material from stages 3 and 4 contained both group A carbohydrate and $\mathrm{M}$ protein, but not $\mathrm{T}$ protein, $\mathrm{E}-4$, or heat-labile antigens. Stage 3 material contained $M$ protein of high specific activity, whereas that from stage 4 contained a significant amount of $M$ protein, but of low specific activity. This was probably attributable to removal of rabbit globulin as well as $M$ protein from the column by $0 \cdot 1 \mathrm{M} \mathrm{NaOH}$. Both stage 3 and 4 material was tested for the presence of rabbit globulin by serum-gel diffusion with goat anti-rabbit IgG. Both fractions yielded reaction lines with this antiserum, but the lines were particularly heavy in fraction 4.

Immunisation of rabbits with immunoabsorbent purified type-1 LYSIN-M. Six rabbits were immunised with various amounts of purified type- $1 \mathrm{M}$ protein in the ear vein and footpads (with complete Freund's adjuvant) as follows: stage 3 material, 1800 units (rabbits 22 and 23); stage 3 material, 1100 units (rabbit 24); stage 4 material, 1100 units (rabbits 25 and 26); stage 4 material, 700 units (rabbit 27). 
Six weeks later, all rabbits exhibited precipitating antibodies for type-1 ACID-M as well as for type-1 LYSIN-M. However, antiserum from rabbits 23 (stage 3 material) and 25 (stage 4 material) reacted very strongly. These antisera were rendered type-1 specific by absorbing with living streptococci; antiserum from rabbit 23 was absorbed with types 6 and 27 and antiserum from rabbit 25 with types 6 and 55. Fewer absorptions were required than with antisera prepared against ammonium-sulphate-precipitated LYSIN-M even though the unabsorbed sera reacted with all 55 heterologous extracts tested. The absorbed antisera were heated at $56^{\circ} \mathrm{C}$ for $45 \mathrm{~min}$. to kill residual streptococci and then tested for bactericidal activity (table V). Both absorbed antisera were bactericidal for type-1 streptococci and retained quite strong reactions for the homologous type-1 acid-heat extracts (ACID-M) while failing to react with acid extracts of types 2 to 61 inclusive.

\section{Type-23 LYSIN-M}

When the procedure used for releasing type-1 $\mathrm{M}$ protein from streptococci with PAL was applied to type-23 cells, M protein was not found in the soluble portion of the lysate, but rather was found only in the sediment. Some type-23

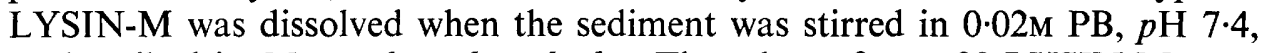
as described in Materials and methods. Three lots of type-23 LYSIN-M were prepared in this manner. Because of difficulties in adapting the quantitative capillary-precipitin test for type- $23 \mathrm{M}$ protein, usually only qualitative data were obtained by the method of Swift et al. (1943).

Type-23 LYSIN-M for purification and immunisation experiments was not subjected to ammonium-sulphate precipitation. When the ultraviolet-absorption spectrum of this type-23 LYSIN-M preparation was checked, much higher readings at $260 \mathrm{~nm}$ than at $280 \mathrm{~nm}$ were obtained. The material causing the

\section{TABLE V}

Indirect bactericidal activity for strain 0001/B1 of absorbed antisera from rabbits immunised with immunoabsorbent purified type-1 L YSIN-M

\begin{tabular}{|c|c|c|c|c|c|}
\hline \multirow[t]{2}{*}{ Serum sample } & \multicolumn{5}{|c|}{$\begin{array}{l}\text { Viable counts (c.f.u. per } 0.1 \mathrm{ml} \text { ) after } 3 \text { hours } \\
\text { incubation of mixtures of serum and heparinised } \\
\text { human blood that initially contained the } \\
\text { following number of c.f.u. per tube. }\end{array}$} \\
\hline & 254 & 74 & 20 & 11 & 3 \\
\hline $\begin{array}{l}\text { Normal rabbit serum } \\
\text { Rabbit } 23 \text {, antiserum } \\
\text { (F-3/6, 27 })\end{array}$ & $\begin{array}{r}U^{*} \\
>400\end{array}$ & $\begin{array}{l}U^{*} \\
188\end{array}$ & $\begin{array}{r}>300 \\
0\end{array}$ & $\begin{array}{r}370 \\
0\end{array}$ & $\begin{array}{r}330 \\
0\end{array}$ \\
\hline $\begin{array}{l}\text { Rabbit } 25, \text { antiserum } \\
(\mathrm{F}-4 / 6,55 t)\end{array}$ & 374 & 290 & 13 & 0 & 0 \\
\hline
\end{tabular}




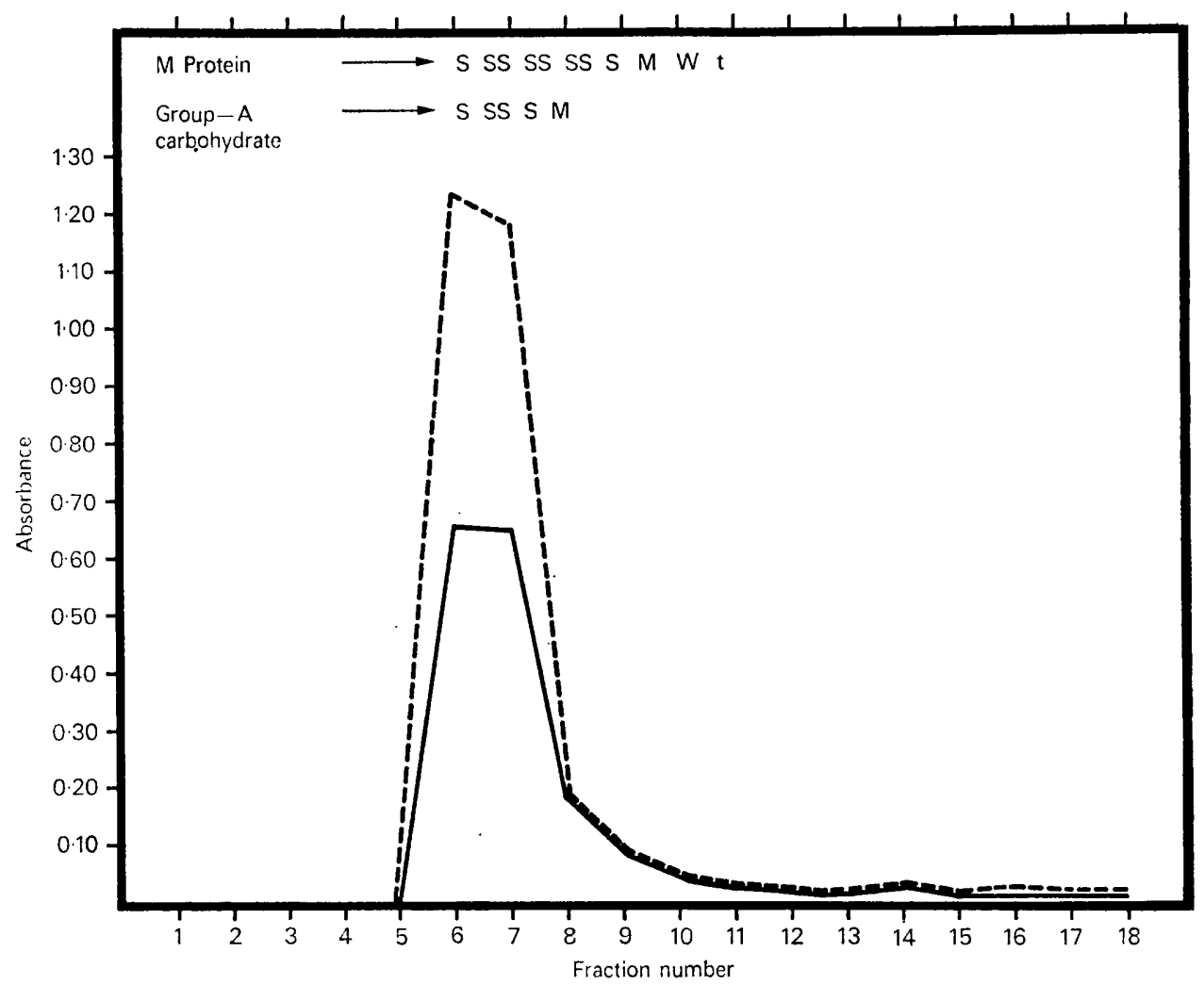

FIG. 3.-Sephadex G-200 gel-filtration of type-23 LYSIN-M : - - $=\mathrm{E}_{260} ;-=\mathrm{E}_{280}$. The volume of each fraction was $2 \cdot 1 \mathrm{ml}$. The first five fractions represent the void volume of the column. Precipitin activity of $M$ protein was measured qualitatively with type-23 antiserum, and group-A carbohydrate activity with group-A antiserum. The reactions were characterised as follows: SS very strong, $\mathrm{S}$ strong, $\mathrm{M}$ moderate, $\mathrm{W}$ weak, and $\mathrm{t}$ trace.

high absorption was assumed to be DNA, since RNAase had been included with PAL when type-23 cells were lysed. Type-23 LYSIN-M was partially purified by two precipitations at its isoelectric point, $p \mathrm{H} \mathrm{4.9}$. Type-23 LYSIN$\mathrm{M}$ was treated with DNAase and then dialysed against $0.02 \mathrm{M} \mathrm{PBS,} p \mathrm{H} 7 \cdot 5$, before being used to immunise rabbits. Details of the procedures are given in Materials and methods.

Characteristics of type-23 LYSIN-M. Two ml of a type-23 LYSIN-M preparation was subjected to Sephadex G-200 gel-filtration.

The results are shown in fig. 3. Type-23 $\mathrm{M}$ protein appeared after the void volume and consisted of high-molecular-weight material. The fractions containing most of the $\mathrm{M}$ protein were also positive for group-A carbohydrate. The material was contaminated with nucleic acids, some of which could be removed by treatment with DNAase. However, the gel-filtration of type-23 LYSIN-M differed from type-1 LYSIN-M in that the elution profile showed the presence of less small-molecular-weight protein, either as $\mathbf{M}$ protein or 
contaminating proteins. This appeared to be due to the fact that the soluble lysate had been discarded and type-23 LYSIN-M had been obtained by dissolution from the sediment in $0.02 \mathrm{M} \mathrm{PB}, p \mathrm{H} \mathrm{7.4}$. Our concern with the nucleic-acid contamination was mostly because it interfered with measurements of protein content. Nucleic acids are poor antigens and probably would not affect antibody formation in rabbits.

Immunogenicity of type-23 LYSIN-M. Four rabbits (nos. 34, 35, 36 and 37) were immunised in the footpads with type-23 LYSIN-M that had been purified by precipitation at its isoelectric point, $p \mathrm{H} \mathrm{4 \cdot 9}$. Antiserum from all four rabbits, taken 5 weeks after immunisation, reacted very strongly with both type-23 ACID-M and LYSIN-M. Antiserum from three of the rabbits was rendered type-23 specific by absorption with living streptococci (antiserum from two of the rabbits (nos. 34 and 35) with type-6 streptococci, and antiserum from rabbit 36 with type 6 and type-55 streptococci). The absorbed antisera were heated at $56^{\circ} \mathrm{C}$ for $45 \mathrm{~min}$. to kill the streptococci and then tested for bactericidal activity (table VI). All absorbed antisera were bactericidal for strain 0223/B1 (type 23). Absorbed antiserum from three of the rabbits (nos. 35 and 36) reacted strongly with an acid extract of type 23, and failed to react with heterologous acid extracts. Antiserum from rabbit 37 was difficult to absorb, and retained a week cross-reaction with type 55 .

\section{Experiments with type-13 strain 0098/B1}

A number of attempts to produce a type-13 LYSIN-M were unsuccessful. It became doubtful whether type-13 $\mathrm{M}$ protein had been rendered soluble. In one attempt, cells were lysed with PAL, and both the concentrated supernatant fluid and the sediment were used to immunise rabbits. No M protein antibodies were detected in the antisera from the six rabbits by either capillary

TABLE VI

Indirect bactericidal activity for strain 0223/B1, type 23, of absorbed antisera from rabbits immunised with partially purified type 23 LYSIN-M

\begin{tabular}{|c|c|c|c|c|c|}
\hline \multirow[t]{2}{*}{ Serum sample } & \multicolumn{5}{|c|}{$\begin{array}{l}\text { Viable counts (c.f.u. per } 0.1 \mathrm{ml} \text { ) after } 3 \text { hours' } \\
\text { incubation of mixtures of serum and heparinised } \\
\text { human blood that initially contained the } \\
\text { following number of c.f.u. per tube. }\end{array}$} \\
\hline & 400 & 153 & 33 & 11 & 11 \\
\hline $\begin{array}{l}\text { Normal rabbit serum } \\
\text { Rabbit } 34 \text {, antiserum } \dagger \\
\text { Rabbit } 35 \text {, antiserum } \dagger \\
\text { Rabbit } 36 \text {, antiserum } \ddagger\end{array}$ & $\begin{array}{r}\mathrm{U}^{*} \\
39 \\
127 \\
6\end{array}$ & $\begin{array}{r}>1000 \\
0 \\
20 \\
0\end{array}$ & $\begin{array}{r}>300 \\
1 \\
1 \\
0\end{array}$ & $\begin{array}{r}96 \\
0 \\
0 \\
0\end{array}$ & $\begin{array}{r}56 \\
0 \\
0 \\
0\end{array}$ \\
\hline
\end{tabular}

c.f.u. = colony-forming units.

* Uncountable.

$\dagger$ Absorbed with type 6 .

$\ddagger$ Absorbed successively with types 6 and 55 . 
precipitin tests or serum-gel diffusion. Further attempts to obtain PAL release of type-13 LYSIN-M for immunisation of rabbits were abandoned.

\section{Electronmicrography of sediment after PAL treatment}

Because of the difficulty in rendering type-13 $\mathrm{M}$ protein soluble after lysis of type-13 cells, the effect of treating them with PAL was examined by electronmicroscopy, as shown in fig. 4. The uranyl-acetate-stained sediment showed many damaged but intact cells. This material contained a few viable cells, as observed by plating the supernate after slow-speed centrifugation, but most of the cells had been killed by exposure to lysin. Previous work (Cohen et al., 1975) showed type-13 cells to be almost as sensitive to PAL as type-1 cells.

Electron micrographs suggested that the PAL damaged the cells in suspension, resulting in some lysis and much leakage of the cell contents. Some dechaining took place also, and in the early lytic periods dramatic drops in $\mathrm{E}_{550}$ were observed. The evidence is that our procedure fell short of completely lysing the suspensions. Cells were damaged and released materials into the supernatant fluid, including $M$ protein in the case of type-1 strain 0001/B1. The damage to type-23 cells was great enough to allow some $\mathbf{M}$ protein to be dissolved from the sediment in 0.02M $\mathrm{PB}, p \mathrm{H} \mathrm{7.4}$. Apparently in the case of type-13 strain 0098/B1, the $M$ protein remained with the cell sediment, was

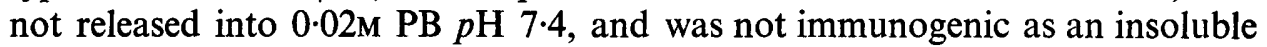
sediment when injected into the footpads of rabbits.

\section{Discussion}

Ever since the classical work on immunochemistry by Landsteiner (1936), microbiologists have been interested in the possibility of using purified antigens to immunise animals for the production of serological reagents. Few objectives in microbiology have been more elusive. Although non-protein antigens such as the carbohydrate of group-A streptococci, the capsular antigens of pneumococci, and the teichoic acids of staphylococci have been isolated and studied, these are haptens and poor immunogens. The $\mathrm{M}$ proteins of group-A streptococci are a special case. Although ACID-M is a protein and immunogenic, rabbits respond to immunisation with the production of hemagglutinating antibodies and bactericidal (opsonising) antibodies, but produce little if any precipitating antibodies (Barkulis and Jones, 1957; Fox and Wittner, 1966; Fox, 1974). Yet the Lancefield (1940) system for serotyping Group-A streptococci is based on the precipitin reaction.

Kantor and Cole (1960) reported immunisation of rabbits with type-1 LYSIN-M. Both precipitating and bactericidal antibodies were produced in response to LYSIN-M. The present report represents a further step, in that satisfactory typing antisera for types 1 and 23 were prepared in rabbits. These antisera, after absorption with selected heterologous types, were specific for homologous acid extracts, remained bactericidal, and retained strong precipitating activities for homologous acid extracts. Preparation and purification of 
$a$

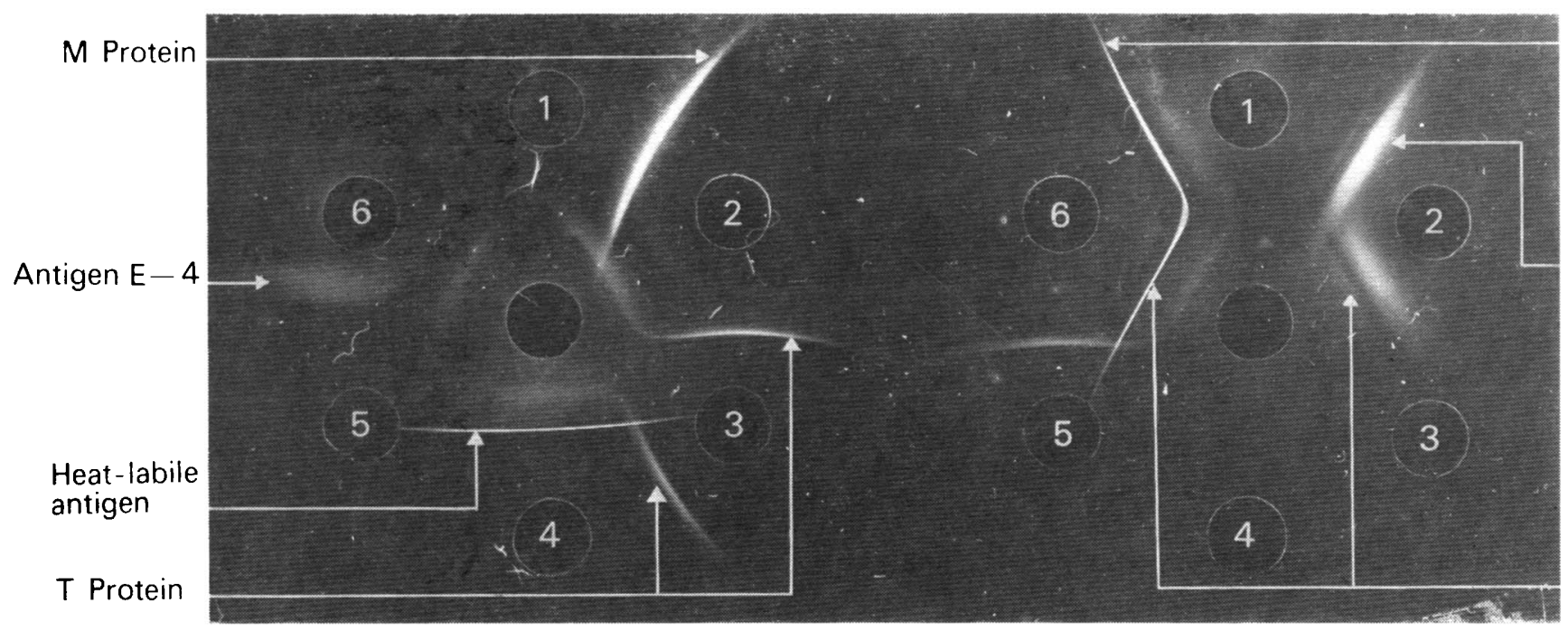

FIG. 2.-Serum-gel diffusion slide. Fig. 2a: centre well, concentrated PAL lysate of strain DS-1134l 66 (M negative, T-type 1); well 1, type-1 ACID-M; well 2, unabsorbed type-1 $\mathbf{M}$ antiserum (after whole-cell immunisation); well 3, type-1 $\mathrm{T}$ antigen; well 4, type-1 $\mathrm{T}$ antiserum; well 5, E-4 antigen; well 6, E-4 antiserum. Fig. $2 b$ : centre well, PAL lysate of strain DS-1134-66 (M negative, T-type 1); well 1, type-1 LYSIN-M preparation 2; well 2, unabsorbed antiserum against ammonium-sulphate-precipitated type-1 LYSIN-M from rabbit 11; wells 3 and 4 empty; well 5, type-1 $\mathrm{T}$ antigen; well 6 , type-1 $\mathrm{T}$ antiserum.
Heat--labile

antigen

M Protein

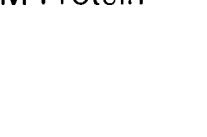

antigens(s) 
Streptococcal M Protein

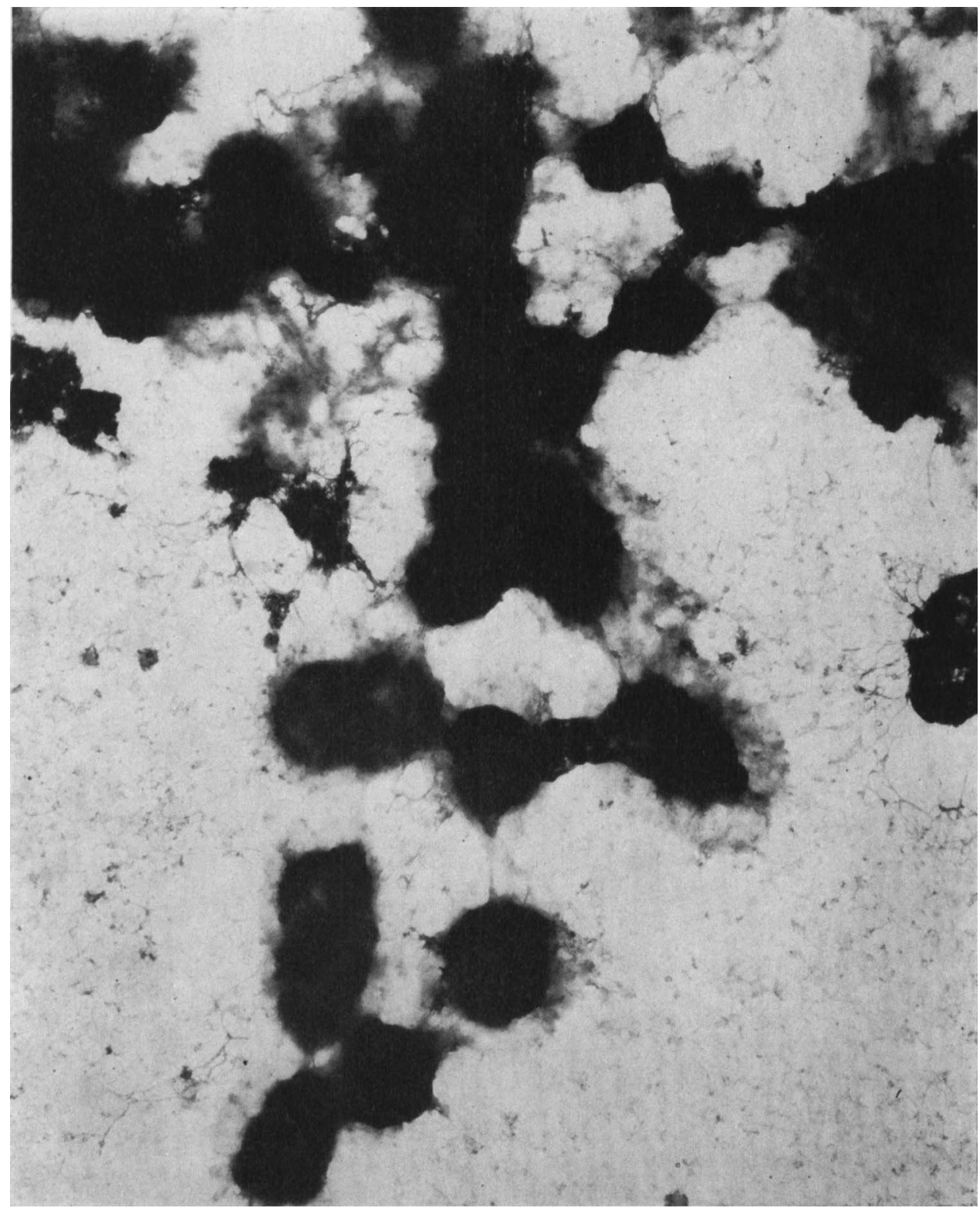

F1G. 4.-Electron micrograph, $\times 22$ 000. Partially lysed type-13, strain-0098/B1, streptococcal cells after treatment with phage-associated lysin. Note leakage of cell materials and variation in density of the incompletely lysed cells. 
LYSIN-M is tedious, and these procedures will not replace the standard method of using whole-cell vaccines, but they are of considerable theoretical interest.

The advantages of immunisation with partially purified LYSIN-M were: (1) rabbits could be immunised successfully with a single inoculation; (2) they did not respond to cross-reacting haptens, such as the group carbohydrate and E-4 antigen when such haptens were present in the vaccines; and (3) the resulting antisera were easy to absorb. It is interesting to note that Conroy and Updyke (1954) found that rabbits made little or no antibody against group-A carbohydrate, when it was present with $\mathbf{M}$ protein in mechanicallydisrupted streptococci.

Despite numerous reports on $\mathrm{M}$ protein from group-A streptococci, the nature of the attachment of $\mathrm{M}$ protein to other cell-surface antigens has not been determined (Fox, 1974). Previous work with LYSIN-M reported by Krause (1958), Kantor and Cole (1960) and Barkulis (1968) suggest a covalent linkage for some of the $\mathbf{M}$ protein, whereas a preliminary paper by Fischetti et al. (1973) reported that some $M$ protein can be released from a type-14 streptococcal strain by a non-ionic detergent. This would indicate a noncovalent attachment. Our data strongly support the concept of a covalent linkage.

The pertinent results are summarised as follows. Significant amounts of group-A carbohydrate co-precipitated with type-1 LYSIN-M in $60 \%$ saturated ammonium sulphate. On Sephadex G-200 gel-filtration of both type-1 and type-23 LYSIN-M, group-A carbohydrate and M protein appeared in the same fractions. Some type-1 LYSIN-M could be precipitated from solution by antiserum against group A. It was possible to absorb LYSIN-M on an immunoabsorbent column containing $\gamma$ globulin from an antiserum predominantly directed against group-A carbohydrate. (More type-1 LYSIN-M adhered to the column than passed through it.) The fractions eluted from the immunoabsorbent column with glycine- $\mathrm{HCl}$ buffer and with $0 \cdot 1 \mathrm{M}$ sodium hydroxide contained type-1 LYSIN-M that was immunogenic in rabbits.

When we began these experiments, we hoped that successful immunisation of rabbits with LYSIN-M would lead to procedures for the preparation of typing antisera for the more difficult types. This was not the case with type 13. Moreover, brief unsuccessful attempts to obtain type- 12 antiserum by immunisation with type-12 LYSIN-M suggest that antisera that are readily prepared with whole cell vaccines, such as type 12 , may be difficult to prepare when starting with PAL release of M protein.

Electron micrographs of the sediment after sequential lysis of type-13 strain 0098/B1 showed many intact but leaking cells. The procedures used in this study did not result in complete lysis of most of the streptococci. It is uncertain whether this was due to the presence of excess cells in the reaction mixture or to changes in the ionic environment after the first few lytic periods. Increased ionic strength might result in the formation of stable spheroplasts from cells added later in the procedure. However, attempts to release $M$ protein by resuspending the sediment in $0.02 \mathrm{M}$ PB did not lead to an obvious change in the amount of sediment on re-centrifugation. We would have expected such a change if the sediment consisted of osmotically fragile spheroplasts.

For strains known to release M protein after treatment with PAL (e.g., type-1 strain 
0001/B1) it might be advantageous if $\mathrm{M}$ protein release could be achieved under conditions of incomplete cell lysis. A procedure that released $\mathbf{M}$ protein preferentially while retaining some of the cytoplasmic materials would be ideal.

It is doubtful if our failure to release $M$ protein from type-13 strain 0098/B1 can be entirely attributed to failure to lyse the cells completely. Conditions that resulted in solution of heat-labile antigen(s) and group carbohydrate failed to yield any soluble type-13 LYSIN-M. It is interesting to note that of 100 rabbits immunised with strain $0098 / \mathrm{B} 1$, type 13 , only one rabbit responded. Yet the strain resists phagocytosis by human leucocytes in the presence of normal rabbit serum, and is opsonised for phagocytosis by human leucocytes by a reference type-13 serum. These are attributes that indicate that the strain posseses type-13 $\mathrm{M}$ protein. M-type 13 streptococci form serum-opacity factor (Top and Wannamaker, 1968), and types for which it has been difficult to prepare specific M-typing serum are usually ones in which this factor is produced (Widdowson, Maxted and Grant, 1970).

It appears that the accessibility of $\mathbf{M}$ protein after PAL treatment varies for different $\mathbf{M}$ types. Type-1 $\mathrm{M}$ protein is readily released from strain $0001 / \mathrm{B} 1$ and is immunogenic. Type$23 \mathrm{M}$ protein from strain 0223/B1, though not in solution after PAL treatment, is somewhat soluble in $0.02 \mathrm{M} \mathrm{PB}, p \mathrm{H} \mathrm{7.4}$, and is immunogenic. All efforts to dissolve the $\mathrm{M}$ protein from strain 0098/B1 (type 13) after PAL treatment failed but this could be done by acid hydrolysis at $100^{\circ} \mathrm{C}$ of whole cells or the sediment from PAL-treated cells.

It is tempting to attribute the failure with type 13 to the size of the M-protein molecule. This might explain both the insolubility of type-13 LYSIN-M in our experiments and the failure of rabbits to respond to type-13 whole-cell inoculation. The response of one rabbit out of 100 to whole-cell vaccination then would be fortuitous. One could speculate that the rabbit's response was the result of in-vivo cleavage of the type-13 $\mathrm{M}$ protein into a molecule of the correct size to invoke the immune response.

Despite numerous recent publications on the $\mathrm{M}$ proteins of group-A streptococci, much of the biochemistry and immunochemistry of these antigens is unknown. Most of the work on M protein has been done with ACID-M, a material that is clearly a breakdown product of a larger protein molecule (Fox and Wittner, 1965, 1966, 1969; Barkulis, 1968; Havlicek, Alouf and Raynaud, 1969). The response of rabbits to LYSIN-M of type 1 and type 23 approximated to the $M$ response observed after whole-cell inoculations, in that precipitins were formed as well as bactericidal antibodies.

The behaviour of LYSIN-M on Sephadex G-200 gel-filtration indicates that much of our LYSIN-M was high-molecular-weight material, which was excluded from the gel. LYSIN-M is more like native M protein than ACID-M, or any hydrolysed $M$ protein for that matter. Though LYSIN-M is difficult to obtain in quantity and difficult to purify, it might prove useful as starting material for characterisation of native $\mathbf{M}$ protein.

\section{SUMMARY}

A phage-associated lysin (PAL) was used to release $\mathrm{M}$ protein from group-A streptococci of types 1 and 23. Much of the lysin-released-M protein (LYSINM) of both types was of high molecular weight, since LYSIN-M appeared just after the void volume on Sephadex G-200 gel-filtration. Some of the LYSIN$\mathbf{M}$ of both types was found to be firmly attached to group-A carbohydrate. Type-1 LYSIN-M was partially purified by ammonium-sulphate precipitation followed by absorption and elution from an immunoabsorbent column containing antibody for group-A carbohydrate. Type-23 LYSIN-M was partially 
purified by precipitation at its isoelectric point, $p \mathrm{H} 4 \cdot 9$. Rabbits immunised in the footpads with either type-1 or type-23 LYSIN-M responded by producing both precipitins and bactericidal (opsonising) antibodies. Some of the antisera were absorbed and rendered specific for homologous acid extracts. The LYSIN-M preparations of both types 1 and 23 were originally contaminated with heat-labile antigen(s). Antibodies to these heat-labile antigen(s), which cross-react from type to type, were found in the type-specific antisera distributed by the Center for Disease Control. The specificity of Lancefield typing antisera depends on their being tested with extracts of streptococci prepared at $p \mathrm{H} 2$ and $100^{\circ} \mathrm{C}$ for $10 \mathrm{~min}$. Although LYSIN-M is more difficult to prepare and purify than acid-heat released $\mathrm{M}$ protein, it might prove useful for studying the nature of native streptococcal $\mathrm{M}$ protein.

The electron micrograph was prepared by Carey S. Callaway, Pathology Division, CDC. J. H. Green provided reference antigens and antisera for identification by serum-gel diffusion of certain well-characterised streptococcal antigens.

\section{REFERENCES}

Axen, R., Porath, J. and Ernback, S. 1967. Chemical coupling of peptides and proteins to polysaccharides by means of cyanogen halides. Nature, Lond., 214, 1302.

Barkulis, S. S. 1968. Chemical and enzymatic studies on the structure and composition of group A streptococcal cell walls. In Current research on group A streptococcus, edited by R. Caravano, Amsterdam, p. 43.

Barkulis, S. S. AND Jones, M. F. 1957. Studies of streptococcal cell walls. I. Isolation, chemical composition, and preparation of M protein. J. Bact., 74, 207.

COHEN, J. O. 1969. Effect of culture medium composition and $p \mathrm{H}$ on the production of $\mathrm{M}$ protein and proteinase by group A streptococci. J. Bact., 99, 737.

Cohen, J. O., Gross, H. and Harrell, W. K. 1975. Simple procedure for production by group C streptococci of phage-associated lysin active against group A streptococci. Appl. Microbiol., 29, 175.

Cohen, J. O. AND PINe, L. 1968. Quantitative aspects of the M protein capillary precipitin test. Appl. Microbiol., 16, 122.

CONROY, E. AND UPDYKE, E. L. 1954. The use of a fraction of mechanically disrupted cells for production of group A streptococcus typing antisera. Science, N.Y., 119, 69.

Fischetti, V. A., Gotschlich, E. C., Siviglia, G. AND Zabriskie, J. B. 1973. The subunit structure of streptococcal M. protein. Abstr. Ann. Meet. Amer. Soc. Microbiol., P242, p. 181.

Fox, E. N. 1964. Antigenicity of the M proteins of group A haemolytic streptococci. J. Immun., 93, 826.

Fox, E. N. 1974. M proteins of group A streptococci. Bact. Rev., 38, 57.

FoX, E. N. AND WiTtNer, M. K. 1965. The multiple molecular structure of the M proteins of group A streptococci. Proc. nat. Acad. Sci., USA, 54, 1118.

FoX, E. N. AND WittNeR, M. K. 1966. Antigenicity of the M proteins of group A hemolytic streptococci. II. Antibody response in rabbits to vaccines prepared with oil emulsion aluminum hydroxide. J. Immun., 97, 86.

Fox, E. N. AND WitTNER, M. K. 1969. New observations on the structure and antigenicity of the $\mathbf{M}$ proteins of the group A streptococcus. Immunochemistry, $\mathbf{6}, 11$.

HavliceK, J., Alouf, J. E. AND Raynaud, M. 1969. Hétérogénéité antigénique de la proteine M de Streptococcus pyogenes type 24. Annls Inst. Pasteur, Paris, 117, 745.

Kantor, F. S. AND COLE, R. M. 1960 . Preparation and antigenicity of M protein released from group A, type 1, streptococcal cell walls by phage-associated lysin. J. exp. Med., 112, 77. 
KRAUSE, R. M. 1958. Studies on the bacteriophages of hemolytic streptococci. II. Antigens released from the streptococcal cell wall by a phage-associated lysin. J. exp. Med., 108, 803.

LANCEFIELD, R. C. 1940. Type specific antigens, $M$ and T, of matt and glossy variants of group A hemolytic streptococci. J. exp. Med., 71, 521.

LANCEFIELD, R. C. 1957. Differentiation of group A streptococci with a common R antigen into three serological types, with special reference to the bactericidal test. J. exp. Med., $106,525$.

LanCefield, R. C. and PerlmanN, G. E. 1952. Preparation and properties of type-specific antigen isolated from a group A, type 1, hemolytic streptococcus. J. exp. Med., 96, 71.

LANDSTEINER, K. 1936. The specificity of serological reactions, Cambridge, Mass.,

LAYNE, E. 1957. Spectrophotometric and turbidimetric methods for measuring proteins. In Methods in enzymology, edited by S. P. Colowick and N. O. Kaplan, New York, vol. 3, p. 447.

Lowry, O. H., Rosebrough, N. J., Farr, A. L. and Randall, R. J. 1951. Protein measurement with the Folin phenol reagent. J. biol. Chem., 193, 265.

PINE, L. AND WATSON, S. J. 1959. Evaluation of an isolation and maintenance medium for Actinomyces species and related organisms. J. Lab. clin. Med., 54, 107.

Swift, H. F., Wilson, A. T. AND LANCEField, R. C. 1943. Typing group A streptococci by M precipitin reactions in capillary pipettes. J. exp. Med., 78, 127.

ToP, F. H., JR AND WANNAMAKER, L. W. 1968. The serum opacity reaction of Streptococcus pyogenes. The demonstration of multiple strain-specific lipoproteinase antigens. J. exp. Med., 127, 1013.

Widdowson, J. P., Maxted, W. R. And Grant, D. L. 1970. The production of opacity in serum by group A streptococci and its relationship with the presence of $\mathbf{M}$ antigen. $J$. gen. Microbiol., 61, 343.

WiLson, A. T. AND WiLEY, G. G. 1963. The cellular antigens of group A streptococci. Immunoelectrophoretic studies of C, M. T, PGP, E4, F, and E antigens of serotype 17 streptococci. J. exp. Med., 118, 527. 